Article

\title{
Phenolic Profile, Antioxidant Capacities and Enzymatic Inhibitory Activities of Propolis from Different Geographical Areas: Needs for Analytical Harmonization
}

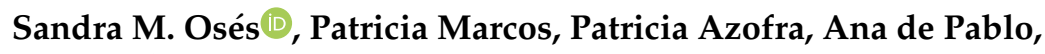 \\ Miguel Ángel Fernández-Muíño * and M. Teresa Sancho * \\ Department of Biotechnology and Food Science, Universidad de Burgos (University of Burgos), Pza. Misael \\ Bañuelos s/n, 09001 Burgos, Spain; smoses@ubu.es (S.M.O.); pmg0035@alu.ubu.es (P.M.); \\ pat0014@alu.ubu.es (P.A.); anadpablotorres@gmail.com (A.d.P.) \\ * Correspondence: mafernan@ubu.es (M.Á.F.-M.); mtsancho@ubu.es (M.T.S.); Tel.: +34-947-258-868 (M.Á.F.-M.); \\ +34-947-258-813 (M.T.S.)
}

Received: 29 November 2019; Accepted: 13 January 2020; Published: 15 January 2020

\begin{abstract}
Propolis is a resinous vegetal exudate modified by bees, and is interesting as a preservative and potentially functional product. This work dealt with studying the common phenolic profiles and antioxidant capacities of 13 bee propolis from different geographical areas. Both hyaluronidase and angiotensin converting enzyme (ACE) inhibitory activities were also assessed and related when possible with particular phenolic compounds. High performance liquid chromatography-ultraviolet detection (HPLC-UV) analysis showed that every propolis contained $p$-coumaric acid (1.2-12.2 $\mathrm{mg} / \mathrm{g}$ ) and ferulic acid (0.3-11.0 mg/g). Pinocembrin, catechin, and caffeic acid phenethyl ester (CAPE) plus galangin were the main flavonoids. Antioxidant activities were higher than $280 \mu \mathrm{mol}$ trolox/g for trolox equivalent antioxidant capacity (TEAC), $0.099 \mathrm{mmol}$ uric acid/g for radical-scavenging effect on hydroxyl radicals, and $0.19 \mathrm{mg} / \mathrm{mL}$ for half maximal inhibitory concentration $\left(\mathrm{IC}_{50}\right)$ of antioxidant activity against superoxide anion radical. Working with solutions of $10 \mathrm{mg} / \mathrm{mL}$ propolis, hyaluronidase inhibitory activity ranged between $0 \%$ and $68.20 \%$, being correlated to ferulic acid content. ACE inhibitory effect determined by HPLC was higher than $78 \%$, being correlated with catechin and $p$-coumaric acid. Therefore, propolis could be useful for food, pharmaceutical, and cosmetic companies, also helping to reduce risk factors for diseases related to oxidative damage, inflammatory processes, and hypertension. This research also highlights the necessity for harmonized analysis methods and the expression of results for propolis.
\end{abstract}

Keywords: propolis; phenolic profile; antioxidant capacities; hyaluronidase inhibitory activity; ACE inhibitory activity

\section{Introduction}

Propolis is a resinous product made by bees mixing plant exudates with beeswax and other substances, such as salivary secretions. Its composition varies depending on the geographic location, botanical origin, and climatic factors [1]. More than 300 compounds have been found in different propolis. Propolis is mainly composed of $40-70 \%$ balsam (flavonoids and phenolic acids), $1-3 \%$ essential oils, $20-35 \%$ waxes and $5 \%$ other substances (most of them coming from pollen or being provided by the bees), such as minerals, polysaccharides, and proteins [2]. To make propolis, bees use raw materials from different botanical species, depending on the flora available in each geographical area, which determines propolis chemical diversity. The basic plant source of European propolis 
(temperate zone), are the bud exudates of trees of the genus Populus sp., mainly black poplar Populus nigra L. [1], whose main constituents are flavonoids with an unsubstituted B-ring, esters of glycerol and cinnamic acids, being the sesquiterpenes the predominant substances within the volatile oil fraction [3]. The main botanical source of Brazilian propolis (tropical zone), is the Asteracean shrub Baccharis dracunculifolia DC. [4], in which terpenoids and prenylated derivates of $p$-coumaric acids prevail [5].

Propolis has been used since ancient times as an antiseptic and cicatrizing agent for wounds due to its properties. The potential bioactive properties of propolis, such as antioxidant, antimicrobial, anti-inflammatory, antiulcer, wound healing, anti-angiogenin, and anti-hyperlipidemic, have been attributed to phenolic compounds, among which flavones, flavonols, flavanones, dihydroflavonols, caffeic acid phenethyl ester (CAPE), and cinnamic acids and their esters are included [6-9]. Nowadays, propolis is used for the growth performance improvement of livestock, as well as for several purposes in food industry, biomedical applications, oral hygiene and cosmetic products [10]. Because of its promising functional properties, there is currently a growing interest in commercializing propolis.

Until June 2019, fifteen health claims related to bee propolis were received by the European Commission [11] alleging the following effects: "antioxidant properties", "respiratory health", "antibacterial and antifungal activities", "throat comfort", "gut health", "supports immune defenses", "maintenance of oral health", "helps to maintain a normal blood circulation" and "hepatoprotective". All health claims were rejected because of probable qualitative and quantitative variations of flavonoids depending on raw materials (different botanical and geographical sources), and the extraction and preparation methods. The panel of assessors also considered that no evidence proved a beneficial physiological effect. All the above occurred because research has been mainly focused on highlighting the differences among propolis of different origins and different bees, so far. Nevertheless, taking a new approach to establish similarities of propolis from different countries is of paramount importance and could help to overcome current limitations, with a positive economic impact on the beekeeping sector.

So far, published research on propolis lacks the necessary harmonization regarding common extraction procedures, common reference standards and, what is more important, common results' expression, making it impossible data comparison among studies. Moreover, literature on antioxidant activity of propolis is mainly focused on one or two general procedures, such as ferric reducting antioxidant power (FRAP), 2,2-diphenyl-picrylhydrazyl assay (DPPH) and/or trolox equivalent antioxidant capacity (TEAC), whose results are correlated [12]. Published research on propolis seldom evaluates antioxidant activity against specific free radicals of physiological interest. Thereby, published data about propolis antioxidant capacity are insufficient to estimate a broad spectrum of the actual propolis antioxidant activity.

The aims of this study were: first, to research possible common phenolics' profiles of bee-propolis from distant geographical areas; second, to assess for first time, a broad spectrum of antioxidant capacity by determining TEAC (the most reliable procedure adaptable to measure both lipophilic and hydrophilic antioxidants based on a single electron transfer reaction mechanism [12]), and antioxidant activities against hydroxyl and superoxide radicals that are important from a physiological point of view, and third, to evaluate hyaluronidase and angiotensin converting enzyme (ACE) inhibitory activities, eventually studying possible correlations between each biological capacity and a particular phenolic group or phenolic compound.

\section{Materials and Methods}

Gallic acid and catechin from Panreac (Barcelona, Spain). CAPE and galangin from TargetMol (Boston, EEUU). Apigenin, chlorogenic acid, kaempferol and pinocembrin from Cymit Quimica, S.L. (Barcelona, Spain). The other standards are from Sigma-Aldrich (Stein-heim, Germany).

This study was carried out on 13 propolis samples harvested in 2015 that came from different geographical areas (6 samples from North-East European countries [P1-P6], 2 samples from the South American tropical zone [P7-P8], and 5 samples from South-West European countries [P9-P13]). All samples were stored in the dark at $-20^{\circ} \mathrm{C}$ until use. 
Propolis extraction was performed accordingly to the harmonized procedure established within the propolis working group of the International Honey Commission: propolis samples were grounded in a marble mortar at $-30^{\circ} \mathrm{C}$. One gram of pulverized propolis sample was weighted and $30 \mathrm{~mL}$ of $70 \%$ food grade ethanol were added. The mixture was kept under mechanical agitation at room temperature and in the absence of light for $24 \mathrm{~h}$. Then, the mixture was filtered (Whatman filter paper No. 4), and the solid was re-extracted in the same conditions as reported. Extraction procedure was repeated until getting absence of phenolics (no colour development) in the solids, adding a few drops of $\mathrm{FeCl}_{3}(5 \%$ in methanol). After the third or fourth extraction, all the extracts were combined in a 100-mL volumetric flask and the volume was adjusted with $70 \%$ ethanol/water. The extraction procedure was performed in triplicate for each sample and the total volume for each sample $(300 \mathrm{~mL})$, was mixed in an amber glass bottle and kept frozen until further use.

Total phenolics were determined in the ethanolic extracts by the method based on the reaction of phenolics with Folin-Ciocalteu reagent [13]. Absorbance was measured at $760 \mathrm{~nm}$, using gallic acid as a standard for the calibration curve. Results were expressed as mg of gallic acid (GA)/g propolis.

Flavone/Flavonol content was analysed by the reaction of these flavonoids with $\mathrm{AlCl}_{3}$ in neutral medium [13]. Absorbance was read at $425 \mathrm{~nm}$, using quercetin as standard for the calibration curve. Results were expressed as $\mathrm{mg}$ of quercetin $(\mathrm{Q}) / \mathrm{g}$ of propolis.

Flavanones/dihydroflavonols content was determined by the reaction of these flavonoids with dinitrophenol [14]. Absorbance was measured at $486 \mathrm{~nm}$, using naringenin as standard for the calibration curve. Results were expressed as $\mathrm{mg}$ of naringenin $(\mathrm{N}) / \mathrm{g}$ of propolis.

For the determination of flavan-3-ols (catechin, rutin, luteolin), these compounds reacted with $\mathrm{AlCl}_{3}$ in alkaline medium [15]. Absorbance was read at $510 \mathrm{~nm}$, using catechin as standard for the calibration curve. Results were expressed as $\mathrm{mg}$ of catechin (C)/g of propolis.

Ethanol extracts of the propolis samples were purified through polyvinylidene difluoride (PVDF) $0.45 \mu \mathrm{m}$ filters (Whatman ${ }^{\mathrm{TM}}$ GE Healthcare, Buckinghamshire, UK) and analyzed by high performance liquid chromatography-ultraviolet detection (HPLC-UV) [16,17], using a chromatograph Varian Pro Star 310 (Varian, Victoria, Australia). $20 \mu \mathrm{L}$ sample was injected. The chromatographic separation was carried out on a reversed-phase Microsorb-MV 100-5 C18 column $(150 \times 4.6 \mathrm{~mm}, 5 \mu \mathrm{m}$ particle size $)$ provided by Agilent Technologies (Agilent, Santa Clara, CA, USA). The mobile phase comprised (A) $0.1 \%$ formic acid in miliQ water and (B) $0.1 \%$ formic acid in acetonitrile. The solvent gradient was: 0-7 min, 0\% B, 7-12 min, 2\% B, 12-20 min, 8\% B, 20-23 min, 10\% B, 23-33 min, 20\% B, 33-45 min, $23 \% \mathrm{~B}, 45-50 \mathrm{~min}, 30 \% \mathrm{~B}, 50-55 \mathrm{~min}, 32 \% \mathrm{~B}$, and $55-60 \mathrm{~min}, 50 \% \mathrm{~B}$. The flow rate was $1 \mathrm{~mL} / \mathrm{min}$ and UV detection was carried out at $280 \mathrm{~nm}$. Quantification was carried out using calibration curves at eight concentration levels $(0.0005-0.5 \mathrm{mg} / \mathrm{mL})$. The linearity of all compounds was satisfactory with $R^{2}$ values $>0.9925$. Limits of detection ranged from $0.0001 \mathrm{mg} / \mathrm{mL}$ to $0.0049 \mathrm{mg} / \mathrm{mL}$. Limits of quantification varied between $0.0009 \mathrm{mg} / \mathrm{mL}$ and $0.0163 \mathrm{mg} / \mathrm{mL}$ (Supplementary Table S1). There were compounds that eluted at the same detection time. Therefore, they were quantified together: naringenin + quercetin, apigenin + kaempferol and CAPE + galangin (Figure 1). 

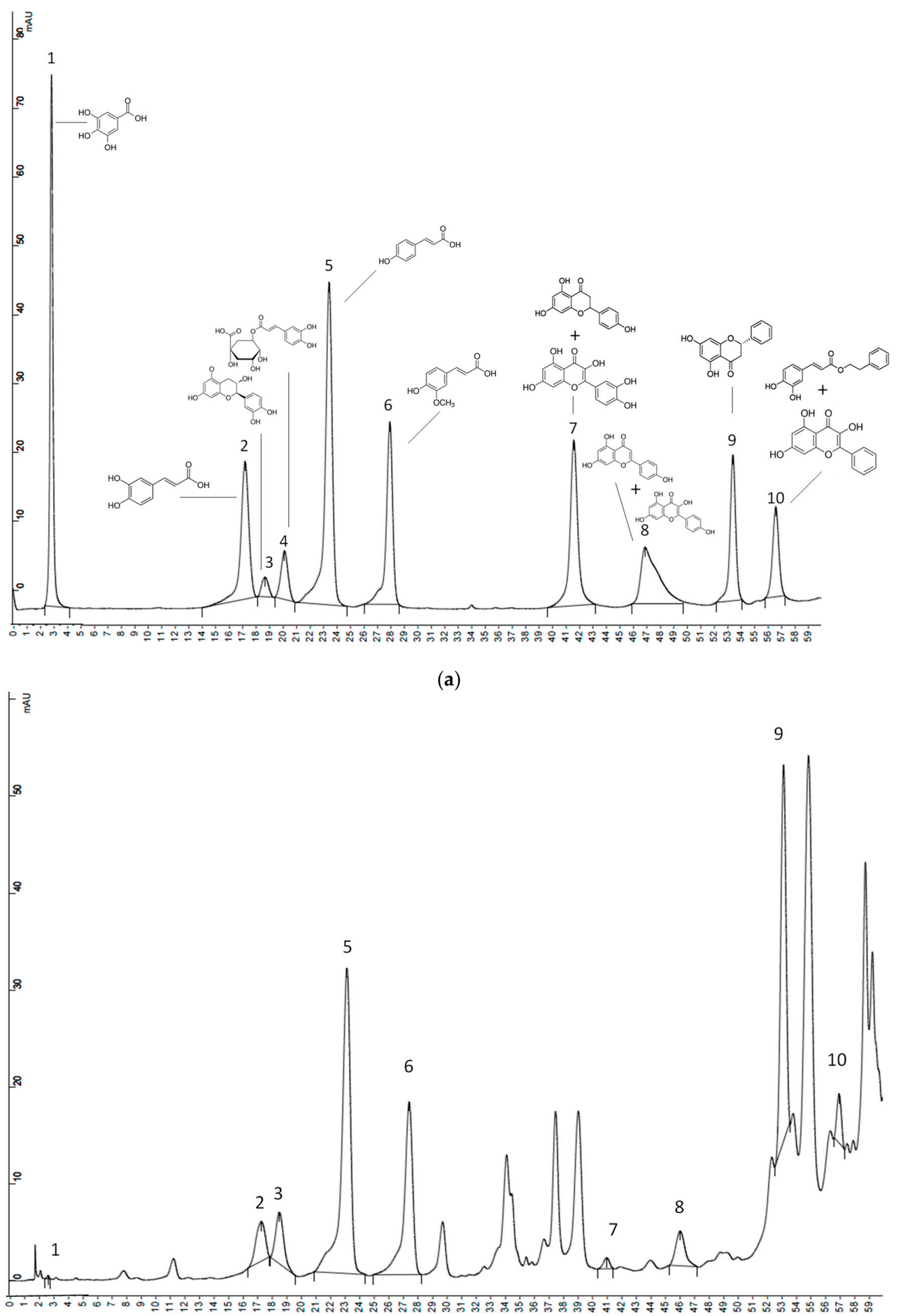

(b)

Figure 1. Chromatograms of the standard phenolic compounds (a) and NE-Europe propolis sample (b) obtained by high performance liquid chromatography-ultraviolet detection (HPLC-UV). Gallic acid (1), caffeic acid (2), catechin (3), chlorogenic acid (4), p-coumaric acid (5), ferulic acid (6), naringenin + quercetin (7), apigenin + kaempferol (8), pinocembrin (9), caffeic acid phenethyl ester (CAPE) + galangin (10). 
Trolox equivalent antioxidant capacity (TEAC) of ethanolic propolis extracts was evaluated mixing $1490 \mu \mathrm{L}$ of $\mathrm{ABTS}^{\bullet+}$ (generated mixing 1:1 ABTS with $\mathrm{K}_{2} \mathrm{~S}_{2} \mathrm{O}_{8}$ and keeping at dark during 16-18 h) with $10 \mu \mathrm{L}$ of sample, standard or blank. Trolox was used as standard for the calibration curve $(0.625-3 \mathrm{mM})$. The percentage inhibition after 6 min was calculated [18]. Results were expressed as $\mu$ mol Trolox (T)/g of propolis.

Antioxidant capacity as radical-scavenging effect on hydroxyl radicals (AOA assay) was measured by quantifying the ability of propolis extracts to inhibit the synthesis of thiobarbituric acid and reactive substances (TBARS) from sodium benzoate under the influence of free radicals produced by Fenton's reaction $[17,19]$. Ethanolic propolis extracts $(10 \mu \mathrm{L})$ were mixed with $490 \mu \mathrm{L}$ of sodium phosphate buffer $(0.1 \mathrm{M}, \mathrm{pH} 7.4), 500 \mu \mathrm{L}$ of sodium benzoate $(0.01 \mathrm{M}), 200 \mu \mathrm{L}$ of $\mathrm{FeSO}_{4}$-EDTA $(2 \mathrm{mM})$ and $200 \mu \mathrm{L}$ of hydrogen peroxide $(0.01 \mathrm{M})$. After $1 \mathrm{~h}$ incubation at $37^{\circ} \mathrm{C}$, the reaction was stopped adding $1 \mathrm{~mL}$ of acetic acid $(20 \%)$, adding later $1 \mathrm{~mL}$ of thiobarbituric acid $(0.8 \% w / v)$ in $\mathrm{NaOH}(50 \mathrm{mM})$. The solution was boiled throughout $10 \mathrm{~min}$ and then cooled in ice. The absorbance was measured at $532 \mathrm{~nm}$ against distilled water. Each sample (A1) had its own control (A0), in which acetic acid (20\%) was added before Fe-EDTA and $\mathrm{H}_{2} \mathrm{O}_{2}$. For each series of analysis, a negative control ( $\mathrm{K} 1$ and $\mathrm{K} 0$ ) was prepared, where the samples had been replaced with phosphate buffer. Further, $1 \mathrm{mM}$ uric acid in $\mathrm{NaOH}(5 \mathrm{mM})$ (U1 and U0) was used as standard. Antioxidant activity was calculated as mmol uric acid (UA)/g of propolis $=0.1 \times(\mathrm{CU}) \times(\mathrm{K}-\mathrm{A}) /(\mathrm{K}-\mathrm{U})$, where $\mathrm{CU}$ is the concentration of uric acid $(1 \mathrm{mM}), \mathrm{K}$ is the absorbance of control (K1-K0), $\mathrm{A}$ is the absorbance of sample (A1-A0) and $\mathrm{U}$ is the absorbance of uric acid solution (U1-U0).

Superoxide anion radical was generated by the xanthine-xanthine oxidase system [20]. In an Eppendorf tube (Eppendorf Ibérica, Madrid, Spain), $0.48 \mathrm{~mL}$ of $0.05 \mathrm{M}$ sodium carbonate buffer ( $\mathrm{pH}$ 10.5), $0.02 \mathrm{~mL}$ of $3 \mathrm{mM}$ xanthine, $0.02 \mathrm{~mL}$ of $3 \mathrm{Mm}$ EDTA, $0.02 \mathrm{~mL}$ of $0.15 \%$ bovine serum albumin (BSA), $0.02 \mathrm{~mL}$ of $0.75 \mathrm{mM}$ nitroblue tetrazolium (NBT) and $0.02 \mathrm{~mL}$ of sample were mixed. After $10 \mathrm{~min}$ at $25^{\circ} \mathrm{C}$ xanthine oxidase $6 \mathrm{mU}$ was added to start the enzymatic reaction that was carried out at $25^{\circ} \mathrm{C}$ during $20 \mathrm{~min}$. Then, the reaction was stopped by adding $0.02 \mathrm{~mL}$ of $6 \mathrm{mM} \mathrm{CuCl}$. The absorbance was measured at $560 \mathrm{~nm}$ against a blank for each sample where the enzyme was not added. Half maximal inhibitory concentration $\left(\mathrm{IC}_{50}\right)$ values for the inhibition of the generation of superoxide anions by the propolis extracts were calculated by measuring the reduction of NBT to form blue formazan.

Hyaluronidase inhibitory activity was assessed by hyaluronidase inhibition assay [21] based on the mechanism of the Morgan-Elson reaction with few modifications. A stock solution of $5 \mathrm{mg} / \mathrm{mL}$ hyaluronic acid sodium salt from Streptococus equi was prepared in water and stored at $4{ }^{\circ} \mathrm{C}$. Hyaluronic acid stock solution $(70 \mu \mathrm{L})$ and $100 \mu \mathrm{L}$ of buffer $(0.2 \mathrm{M}$ sodium formate, $0.1 \mathrm{M} \mathrm{NaCl}$ and $0.2 \mathrm{mg} / \mathrm{mL}$ BSA, pH adjusted to 3.68 with formic acid) were added to $200 \mu \mathrm{L}$ milliQ water and $50 \mu \mathrm{L}$ sample. The mixture was heated at $37^{\circ} \mathrm{C}$ for $10 \mathrm{~min}$ before starting the reaction by addition of $50 \mu \mathrm{L}$ of hyaluronidase from bovine testes type IV-S $(1400 \mathrm{U} / \mathrm{mL})$ prepared in $0.9 \% \mathrm{NaCl}$. The mixture was incubated for $1 \mathrm{~h}$ at $37^{\circ} \mathrm{C}$ in a water bath. The enzymatic reaction was stopped by adding $100 \mu \mathrm{L}$ of 0.8 $\mathrm{M}$ potassium tetraborate and then, incubated $3 \mathrm{~min}$ in water-bath at ebullition. The test tubes were cooled at room temperature and $750 \mu \mathrm{L}$ of $p$-dimethylaminobenzaldehyde (DMAB) was added (DMAB was prepared dissolving $2 \mathrm{~g}$ of DMAB in a mixture of $2.5 \mathrm{~mL}$ of $10 \mathrm{~N} \mathrm{HCl}$ and $17.5 \mathrm{~mL}$ of glacial acetic acid, further diluted 1:2 with glacial acetic acid immediately before use). The tubes were incubated for $20 \mathrm{~min}$ at $37^{\circ} \mathrm{C}$ and the colour of the resulting product was read at $586 \mathrm{~nm}$ against a blank sample (where enzyme and sample had been substituted by buffer). Enzyme activity was defined as 1 unit (U) of hyaluronidase that catalyzes the liberation of $1 \mu \mathrm{mol} N$-acetyl-D-glucosamine (NAG) per min under specified conditions. NAG standard solutions (in the range between 0 and $2 \mu \mathrm{mol}$ per test), were used as standard for calibration curves. With the NAG formed in each enzymatic reaction and using the linear regression equation, the percentage of enzyme inhibition was calculated as $\%$ Inhibition $=(\mathrm{A}-$ B)/A $\times 100$, where $\mathrm{A}$ was $\mu \mathrm{mol}$ of NAG in the positive control (where $\mu \mathrm{L}$ of sample was substituted by buffer) and B was $\mu \mathrm{mol}$ of NAG of each sample reaction. 
ACE inhibitory activity was determined by HPLC-UV [22]. The method was based on the hydrolysis of N-hippuryl-histidyl-leucine (HHL) into hippuric acid (HA) and His-Leu (HL) by the angiotensin converting enzyme (ACE). Propolis sample $(10 \mu \mathrm{L})$ was mixed with $30 \mu \mathrm{L}$ of ACE $(60 \mathrm{mU} / \mathrm{mL})$ prepared in buffer (sodium chloride $0.3 \mathrm{M}$, potassium phosphate $0.1 \mathrm{M} \mathrm{pH} 8.3$ ) and incubated $10 \mathrm{~min}$ at $37^{\circ} \mathrm{C}$. Then, $90 \mu \mathrm{L}$ of HHL solution $(5 \mathrm{mM})$, pre-incubated at $37^{\circ} \mathrm{C}$, was added to tubes and the mixture was incubated $1 \mathrm{~h}$ at $37^{\circ} \mathrm{C}$. To stop the reaction, $8 \mu \mathrm{L}$ of $5 \mathrm{M} \mathrm{HCl}$ was used. After enzymatic reaction, each sample was filtered through $0.2 \mu \mathrm{m}$ PVDF filter unit (WhatmanTM GE Healthcare, Buckinghamshire, UK). The concentration of HA released in the enzymatic reaction was determined on a HPLC system (Pro Star Varian, Victoria, Australia), using a $\mathrm{C}_{18}$ Ultrasphere ODS column $(4.6 \mathrm{~mm} \times 250 \mathrm{~mm})\left(\right.$ Beckmann ${ }^{\circledR}$, Indianapolis, USA). $25 \mu \mathrm{L}$ sample was injected. Mobile phase was a solution of acetonitrile $12.5 \%$ and trifluoroacetic acid $0.1 \%$ in water. Flow rate was $1 \mathrm{~mL} / \mathrm{min}$ and a Pro star $325 \mathrm{UV}$-Vis detector measuring the optical density at $228 \mathrm{~nm}$ during $15 \mathrm{~min}$. Data were analysed using Star Chromatography Workstation version 6.41 software (Varian, Victoria, Australia). External standard solutions of HA (1-1000 $\mu \mathrm{M})$ were used for the calibration curve. Each day of analysis, a blank (without enzyme and sample), and a control (without sample), were also injected. Furthermore, each sample had its own blank, where the enzyme was substituted by buffer. The results were expressed as $\%$ inhibitory ACE activity $=([$ HAcontrol $]-$ [HAsample] $) /[$ HAcontrol] $\times 100 \%$.

Each assay was carried out in triplicate. All results were evaluated by multiple range tests assessed by Turkey HSD test $(p<0.05)$. Pearson correlations were applied to the results. Statistical software Stagraphics Ceturion XVII (Statgraphics Technologies, Inc., The Plains, VA, USA)) was used.

\section{Results and Discussion}

\subsection{Total Phenolic Content}

The phenolic content of propolis ranged between $65.49 \mathrm{mg} \mathrm{GA} / \mathrm{g}$ and $228.40 \mathrm{mg} \mathrm{GA} / \mathrm{g}$. Literature references describe a variety of ranges for total phenolics of propolis from different geographical origins, depending on both standard and solvent used. Operating with gallic acid as standard and methanol as solvent/diluent, total phenolics of Portuguese and Brasilian propolis ranged from 29.5 to $137 \mathrm{mg} / \mathrm{g}[23,24]$. Using gallic acid as standard and ethanol as solvent, higher amounts of phenols were obtained (150-340 mg/g), for propolis from Spain [25,26], Poland [27] and China [28]. Employing pinocembrin as standard, a phenolic content of $62.7 \mathrm{mg} / \mathrm{g}$ was found for Portuguese propolis [29]. Utilizing chlorogenic acid as standard, amounts of $287 \mathrm{mg} / \mathrm{g}$ were obtained in Slovenian propolis [30]. Using caffeic acid as standard, total phenolics' values ranged from 0.74 to $338 \mathrm{mg} / \mathrm{g}$ in propolis from Morocco [31] and Greece [32]. A total phenolic content between 30 and $329 \mathrm{mg} / \mathrm{g}$ was obtained when a mixture of caffeic acid:galangin:pinocembrim (1:1:1) was used as standard for Portuguese [33] and Brasilian [34] propolis. Our results also showed a great variability. However, it is important to highlight the fact that, regarding propolis' total phenolic content, the comparison of data is very difficult because, on the one hand, there is not a consensus standard for the calibration curve (gallic acid, caffeic acid, chlorogenic acid, pinocembrin, galangin, and mixes of them are used in different studies), and on the other hand, there is still a worrisome lack of regulation regarding standardized procedures, although reliable standard methods for Apis mellifera propolis were proposed [35].

\subsection{Total Flavonoids Content}

In respect of flavones and flavonols, our values ranged between $18.48 \mathrm{mg} \mathrm{Q} / \mathrm{g}$ and $83.76 \mathrm{mg} \mathrm{Q} / \mathrm{g}$. Flavanones and dihydroflavonols ranged between 25.07 and $128.46 \mathrm{mg} \mathrm{N} / \mathrm{g}$. As for flavanols, values ranged between 27.89 and $108.18 \mathrm{mg} \mathrm{C/g}$. Our results of flavone and flavonols as well as flavanones and dihydroflavonols were similar to those obtained by other researchers in propolis from a variety of geographical origins, with results of 13-62 mg Q/g flavone and flavonols, and 55-100 mg N/g flavanones and dihydroflavonols $[23,26-29,36]$. Flavanones were described as the main constituents of poplar-type propolis [14]. However, in this study the results for all flavonoids' groups were quite 
similar. Flavanols were hardly researched by spectrophotometric assays. Similar values than ours were obtained for Ethiopian propolis, ranging from 14.76 to $68.88 \mathrm{mg} \mathrm{C/g}$ [37] and lower for Thai propolis, with an average of $3.40 \mathrm{mg} \mathrm{C} / \mathrm{g}$ [38].

\subsection{Quantification of Phenols Compounds Using HPLC-UV}

Figure 1 shows two chromatograms: (a) corresponds to a mixture of phenolics' standards and (b) to the phenolic profile of one sample from NE-Europe. Table 1 shows the phenolic compounds (mg/g), quantified in propolis by HPLC-UV. In our study, gallic acid was only quantified in three samples and chlorogenic acid in six samples. Flavonoids were found in higher concentration than phenolic acids, being catechin and pinocembrin the main flavonoids. Our North-East European propolis showed all phenolic compounds, except gallic and chlorogenic acids, being catechin and pinocembrin together with CAPE + galangin the major compounds. In literature references, Slovenian propolis showed the lowest results for gallic acid, and trace concentrations of chlorogenic acid [30]; Hungarian propolis had pinocembrin and chrysin as the major phenolics, being chlorogenic acid also described [39]. Polish propolis [40] were characterized by $p$-coumaric acid, 2-acetyl-1,3-di- $p$-coumarylglycerol, and $p$-coumaric acid benzyl ester together with galangin and chrysin as the main polyphenols. South-West European propolis didn't contain gallic acid, but had higher amounts of pinocembrin and caffeic acid, and lower content of ferulic acid than our other propolis. In Italian and Spanish propolis, different studies showed that pinocembrin was one of the most important flavonoids and isoferulic, ferulic and caffeic acids were the major phenolic acids [41-43]. Two samples of propolis from South America showed different phenolic compositions, probably because they were from different botanical and geographical origins or were harvested in different seasons [44], being $p$-coumaric acid the major phenolic compound in one of the samples, and catechin, CAPE and galangin the major phenolics in the other sample.

Even although propolis samples exhibited different phenolics' profiles agreeing with literature [40], two acids: $p$-coumaric (1.2-12.2 $\mathrm{mg} / \mathrm{g}$ propolis) and ferulic (0.3-11.0 $\mathrm{mg} / \mathrm{g}$ propolis) were found in all of our samples, regardless their origin. Therefore, research about biological activities related to these two acids is of great interest in order to provide with some of the necessary evidences for future proposals regarding propolis' health claims. All propolis also exhibited quantifiable values for the sums of naringenin + quercetin (0.3-3.2 mg/g propolis), apigenin + Kaempferol (0.6-32.2 mg/g propolis) and CAPE + galangin (2.4-110.6 mg/g propolis), but in this case, given that the sum of two compounds was involved, it was not possible to define if one or both compounds were common to all samples. Apart from the thirteen standard compounds quantified (Figure 1b), some other non-identified peaks were present in the samples, which is usual, due to the huge variety of phenols described in the literature in propolis around the word [30,39-44].

With regard to the similarities or differences of our results for individual compounds with those of the literature references, it is essential to point out that the comparison is extremely difficult because the concentration units are different. One research gave the results as percentage of peaks' areas [40], while other studies showed the values as $\mu \mathrm{g}$ or $\mathrm{mg}$ compound/g propolis extract or balsam $[30,39,41,43,44]$, and another one expressed the results as $\mathrm{mg} / \mathrm{g}$, not specifying if the denominator referred to $\mathrm{g}$ extract (or balsam) or to $g$ propolis [42], although it is likely that it was g propolis, because in the units for other phenolic-related parameters of the same study the denominator referred to g propolis [42]. The lack of uniformity regarding analytical procedures and expression of results highlights the urgency of the development of a legal regulation for propolis. 
Table 1. Phenolic compounds (mg/g propolis) quantified by HPLC-UV in propolis from different geographical origins.

\begin{tabular}{|c|c|c|c|c|c|c|c|c|c|c|c|}
\hline Zone & Sample & Gallic Acid & Caffeic Acid & Catechin & $\begin{array}{l}\text { Clorogenic } \\
\text { Acid }\end{array}$ & $\begin{array}{c}p \text {-Coumaric } \\
\text { Acid }\end{array}$ & Ferulic Acid & $\begin{array}{l}\text { Naringenin + } \\
\text { Quercetin * }\end{array}$ & $\begin{array}{c}\text { Apigenin }+ \\
\text { Kaempferol * }\end{array}$ & Pinocembrin & $\begin{array}{c}\text { CAPE + } \\
\text { Galangin * }\end{array}$ \\
\hline $\mathrm{RT}(\mathrm{min})$ & & 2.81 & 17.23 & 18.71 & 20.17 & 23.47 & 27.98 & 41.64 & 46.93 & 53.45 & 56.63 \\
\hline NE-Europe & 1 & $0.3 \pm 0.0^{\mathrm{a}}$ & $0.7 \pm 0.1^{\mathrm{a}}$ & $29.1 \pm 0.5^{\mathrm{e}}$ & ND & $9.5 \pm 0.2^{b c}$ & $11.0 \pm 0.2^{\mathrm{e}}$ & $0.4 \pm 0.0^{\mathrm{a}}$ & $4.5 \pm 0.1^{\mathrm{ab}}$ & $4.6 \pm 0.3^{b}$ & $14.8 \pm 0.4^{\mathrm{de}}$ \\
\hline NE-Europe & 2 & $0.3 \pm 0.0^{\mathrm{a}}$ & $2.2 \pm 0.1^{b}$ & $19.8 \pm 1.1^{\mathrm{d}}$ & ND & $8.1 \pm 0.3^{b}$ & $7.9 \pm 0.3^{\mathrm{d}}$ & $0.5 \pm 0.0^{b c}$ & $15.8 \pm 0.9^{\mathrm{d}}$ & $16.5 \pm 0.3^{d}$ & $5.8 \pm 0.4^{\mathrm{ab}}$ \\
\hline NE-Europe & 3 & ND & $6.4 \pm 0.5^{\mathrm{e}}$ & $0.9 \pm 0.2^{\mathrm{a}}$ & $1.4 \pm 0.7^{\mathrm{a}}$ & $2.3 \pm 0.6^{\mathrm{a}}$ & $1.4 \pm 0.1 \mathrm{abc}$ & $0.4 \pm 0.0^{\mathrm{a}}$ & $12.7 \pm 1.1^{\mathrm{cd}}$ & $56.6 \pm 1.1 \mathrm{~g}$ & $18.9 \pm 1.8^{\mathrm{e}}$ \\
\hline NE-Europe & 4 & $<\mathrm{LQ}$ & $1.6 \pm 0.0^{\mathrm{b}}$ & $32.9 \pm 0.0^{f}$ & ND & $11.4 \pm 0.3^{c}$ & $6.0 \pm 0.2^{d}$ & $0.6 \pm 0.0^{\mathrm{cd}}$ & $0.6 \pm 0.9^{\mathrm{a}}$ & $13.9 \pm 0.3^{d}$ & $13.3 \pm 0.8^{\text {cde }}$ \\
\hline NE-Europe & 5 & $<\mathrm{LQ}$ & $3.5 \pm 0.3^{c}$ & $3.7 \pm 0.4^{\mathrm{b}}$ & $0.8 \pm 0.5^{\mathrm{a}}$ & $2.9 \pm 0.7^{\mathrm{a}}$ & $3.4 \pm 0.3^{c}$ & $0.4 \pm 0.1^{\mathrm{a}}$ & $4.1 \pm 2.6^{\mathrm{ab}}$ & $0.4 \pm 0.2^{\mathrm{a}}$ & $71.9 \pm 2.7^{f}$ \\
\hline NE-Europe & 6 & $<\mathrm{LQ}$ & $0.8 \pm 0.0^{\mathrm{a}}$ & $52.1 \pm 1.2 \mathrm{~g}$ & ND & $7.8 \pm 0.2^{b}$ & $6.3 \pm 0.1^{\mathrm{d}}$ & $0.6 \pm 0.0^{\mathrm{cd}}$ & $1.4 \pm 0.2^{\mathrm{a}}$ & $9.5 \pm 0.8^{c}$ & $2.4 \pm 0.1^{\mathrm{a}}$ \\
\hline S America & 7 & $0.3 \pm 0.0^{\mathrm{a}}$ & $0.8 \pm 0.0^{\mathrm{a}}$ & ND & $0.9 \pm 0.0^{\mathrm{a}}$ & $8.1 \pm 0.1^{b}$ & $0.4 \pm 0.0^{\mathrm{a}}$ & $3.2 \pm 0.1 \mathrm{~g}$ & $5.5 \pm 0.1 \mathrm{ab}$ & $1.3 \pm 0.1^{\mathrm{a}}$ & $18.0 \pm 0.7^{\mathrm{e}}$ \\
\hline S America & 8 & $<\mathrm{LQ}$ & $<\mathrm{LQ}$ & $20.8 \pm 0.1^{\mathrm{d}}$ & $0.2 \pm 0.0^{\mathrm{a}}$ & $1.2 \pm 0.0^{\mathrm{a}}$ & $0.3 \pm 0.0^{\mathrm{a}}$ & $0.5 \pm 0.0^{\mathrm{b}}$ & $1.5 \pm 0.1^{\mathrm{a}}$ & $<\mathrm{LQ}$ & $9.0 \pm 0.2^{\mathrm{bcd}}$ \\
\hline SW-Europe & 9 & ND & ND & $34.1 \pm 0.9^{\mathrm{f}}$ & ND & $2.8 \pm 0.1^{\mathrm{a}}$ & $0.8 \pm 0.0^{\mathrm{ab}}$ & $0.7 \pm 0.0^{\mathrm{e}}$ & $5.6 \pm 0.3^{\mathrm{ab}}$ & $33.3 \pm 1.4^{\mathrm{f}}$ & $7.6 \pm 0.5 \mathrm{abc}$ \\
\hline SW-Europe & 10 & ND & $6.0 \pm 0.1^{\mathrm{e}}$ & ND & ND & $2.4 \pm 0.0^{\mathrm{a}}$ & $1.0 \pm 0.0^{\mathrm{ab}}$ & $0.3 \pm 0.0^{\mathrm{a}}$ & $6.3 \pm 0.5 \mathrm{abc}$ & $28.3 \pm 0.2^{\mathrm{e}}$ & $13.4 \pm 1.0^{\text {cde }}$ \\
\hline SW-Europe & 11 & $<\mathrm{LQ}$ & $6.5 \pm 0.3^{\mathrm{e}}$ & $6.3 \pm 1.6^{c}$ & $7.3 \pm 4.1^{b}$ & $12.2 \pm 3.2^{c}$ & $2.9 \pm 0.8^{b c}$ & $1.0 \pm 0.1^{\mathrm{f}}$ & $11.4 \pm 0.4 \mathrm{bcd}$ & $13.7 \pm 0.6^{\mathrm{d}}$ & $72.0 \pm 3.1^{\mathrm{f}}$ \\
\hline SW-Europe & 12 & ND & $4.6 \pm 0.4^{\mathrm{d}}$ & $1.7 \pm 0.4^{\mathrm{ab}}$ & $0.4 \pm 0.3^{\mathrm{a}}$ & $2.0 \pm 0.2^{\mathrm{a}}$ & $1.9 \pm 0.1 \mathrm{abc}$ & $0.4 \pm 0.1^{\mathrm{a}}$ & $32.2 \pm 7.4 \mathrm{e}$ & $25.6 \pm 2.6^{\mathrm{e}}$ & $13.0 \pm 2.7 \mathrm{cde}$ \\
\hline SW-Europe & 13 & ND & $6.6 \pm 0.1^{\mathrm{e}}$ & ND & ND & $3.0 \pm 0.0^{\mathrm{a}}$ & $2.3 \pm 2.8 \mathrm{abc}$ & $0.3 \pm 0.0^{\mathrm{a}}$ & $4.0 \pm 0.2^{\mathrm{ab}}$ & $33.9 \pm 1.1^{\mathrm{f}}$ & $110.6 \pm 6.0 \mathrm{~g}$ \\
\hline
\end{tabular}

${ }^{\mathrm{a}-\mathrm{g}}$ different letters means significant difference $(p<0.05)$ for the same phenol compound; LQ: Limit quantification; ND: Not detected; * These compounds elute at the same retention time

(RT), so they were quantified together. NE: North-East; S: South; SW: South-West. 


\subsection{Antioxidant Capacities}

Antioxidant capacities of our propolis ethanolic extracts were assessed for the first time against three different free radicals, namely $\mathrm{ABTS}^{\bullet+}$, hydroxyl radical, and superoxide anion radical. This important from the point of view of assessing a broad spectrum of antioxidant activity of this product as explained in the introduction section. The results are shown in Figure 2.

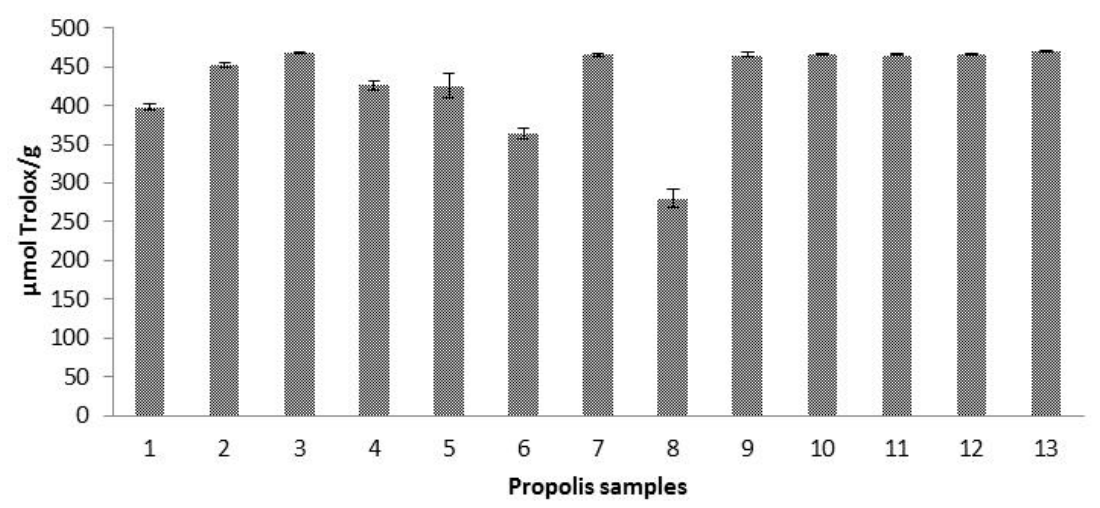

(a)

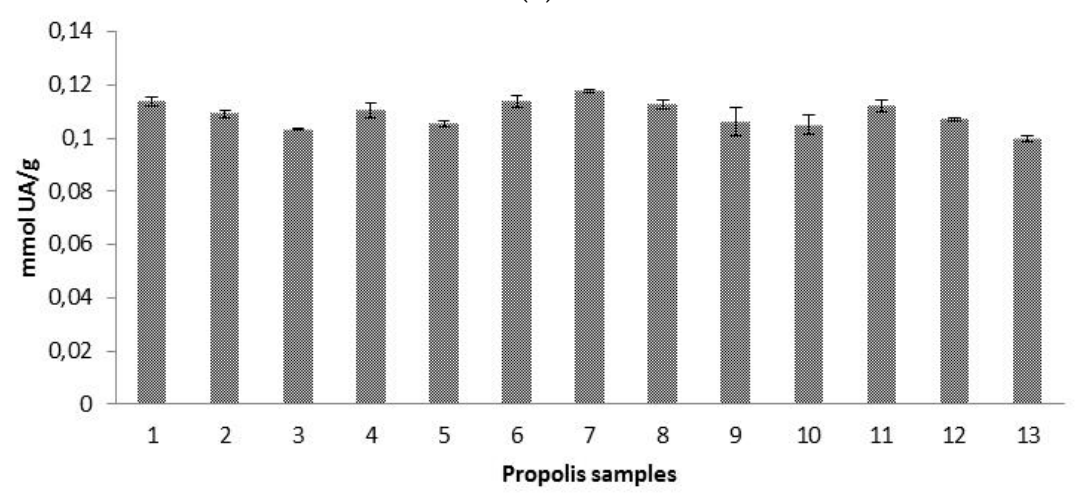

(b)

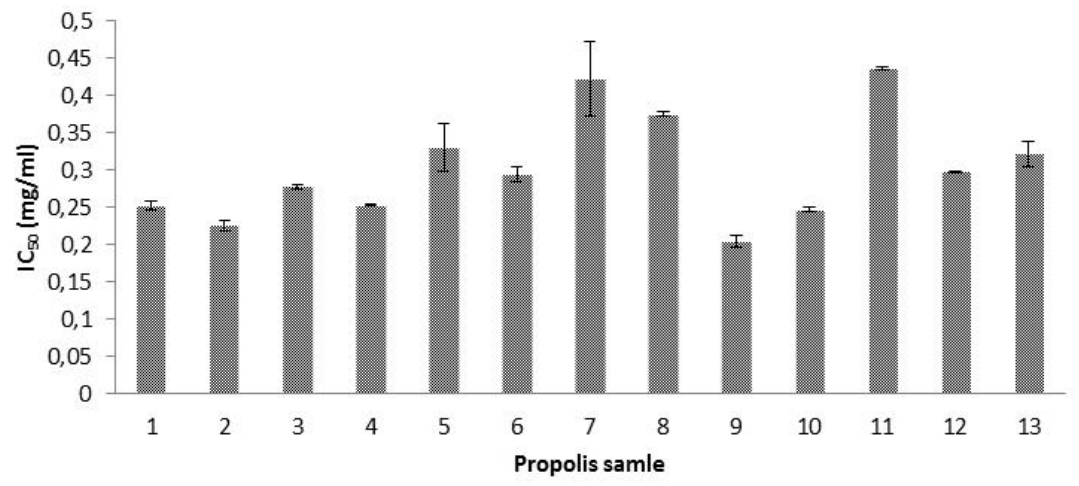

(c)

Figure 2. Mean values $(n=3)$ of: (a) Trolox equivalent antioxidant capacity (TEAC) expressed as $\mu \mathrm{mol}$ Trolox/g of propolis, (b) radical-scavenging activity on hydroxyl radicals expressed as mmol uric acid (UA)/g of propolis, and (c) radical-scavenging effect on superoxide radicals expressed as half maximal inhibitory concentration $\left(\mathrm{IC}_{50}\right)(\mathrm{mg} / \mathrm{mL})$. Error bars represent the standard deviation for each data point. 


\subsubsection{Antioxidant Capacity by $\mathrm{ABTS}^{\bullet+}$ Scavenging Activity Test}

Results of trolox equivalent antioxidant capacity (TEAC) ranged between 280 and $470 \mu \mathrm{mol}$ $\mathrm{T} / \mathrm{g}$ propolis. Like the above-mentioned case of the contrasting units found in literature references for the concentration of individual phenolic compounds, the same problem occurs with regard to literature TEAC values, aggravated by the use of different reagents and alcohol concentrations. Higher TEAC results than ours were obtained in Spanish propolis $[25,26]$, but the results were shown as $\mu \mathrm{mol} \mathrm{T} / \mathrm{g}$ extract. Moreover, in one of the references [25], 90\% ethanol was used for balsam extraction, in contrast to the $70 \%$ ethanol used for our present research. It was claimed that the higher the concentration of ethanol was, the higher the antiradical activity of propolis extracts was, being also this activity significantly affected by $\mathrm{pH}$ of the solvent used [27]. Using $80 \%$ ethanol as extracting agent, in Brazilian propolis, ranges between 25.5 and $439.2 \mu \mathrm{mol} \mathrm{T} / \mathrm{g}$ sample were obtained, not specifying if the denominator referred to $g$ extract or g propolis, but being likely to be g propolis, because in the same study and regarding DPPH antioxidant activity, the denominator referred to g propolis [45].

In order to check possible synergistic or antagonistic effects among single phenolic compounds detected in our propolis samples, antioxidant activity against $\mathrm{ABTS}^{\bullet+}$ radical was assessed for individual commercial standards of phenolic compounds (Supplementary Table S2). For each sample, the TEAC result corresponding to the addition of the TEAC value provided by each assayed compound quantified by HPLC-UV was calculated (Supplementary Table S3). The TEAC value for each phenolic standard was different, agreeing with a previous study in which antioxidant activity of phenolic acids and flavonoids derived from propolis was claimed to be dependent on their structure, number of hydroxyl groups in their molecules, steric effects, position of hydroxyl groups, as well as the substituents on the aromatic ring, the double bond between C-2 and C-3 and the presence of the 4-oxo group, among other factors [46]. In general, our propolis samples showed antioxidant activities higher than those resulting from the addition of phenolic compounds quantified by HPLC-UV, so that the actual antioxidant activity of propolis appears to be linked to the synergistic effect of different phenolic compounds, and to the effect of other non-phenolic antioxidant substances. Ferulic acid is likely to be the main phenolic compound responsible for propolis TEAC, because it is present in all samples and exhibits a high TEAC value. It is probable that catechin also has an important contribution to TEAC, because of its relatively high concentration in the vast majority of propolis samples.

\subsubsection{Antioxidant Capacity as Radical-Scavenging Effect on Hydroxyl Radicals (AOA Assay)}

Our propolis showed a scavenging ability against hydroxyl radical ranging between 0.099 and $0.117 \mathrm{mmol} \mathrm{UA} / \mathrm{g}$ propolis $(0.99-1.17 \mathrm{mM} \mathrm{UA})$, which was slightly higher than that of the uric acid standard $(1 \mathrm{mM})$. Values between 0.053 and $0.068 \mathrm{mmol} \mathrm{UA} / \mathrm{g}$ propolis were obtained in Tunisian propolis [16]. Hydroxyl radical scavenging activity was also researched in other propolis using different units for the expression of results, what makes impossible a comparison among data, underlining the urgent need for an agreement regarding methodology and results' expression. In two papers, hydroxyl radical scavenging activity was quantified as percentage inhibition rate with a $76.7 \%$ inhibition rate for Chinese propolis [47] and values ranging from $40-80 \%$ for Brazilian propolis [48].

\subsubsection{Antioxidant Capacity as Superoxide Radical-Scavenging Activity}

Our antioxidant activity against superoxide anion radical showed $\mathrm{IC}_{50}$ values between 0.20 and $0.44 \mathrm{mg} / \mathrm{mL}$. Higher superoxide scavenging activities were obtained in propolis from Algarve (southern Portugal) with $\mathrm{IC}_{50}$ values ranging from 0.01 to $0.053 \mathrm{mg} / \mathrm{mL}$ in methanolic extracts [36]. Using a propolis concentration of $75 \mathrm{mg} / \mathrm{mL}$, our inhibition rates $(77.41-100 \%)$, were similar to those obtained in Brazilian aqueous extracts, with values of $86.1 \%$ at $5 \mathrm{mg} / \mathrm{mL}$, and $100 \%$ at $50 \mathrm{mg} / \mathrm{mL}$ [49], and in Japanese ethanolic extracts, with results around $80 \%$ at a concentration of $1 \%$ [20]. However, we consider that the comparison of results is not reliable enough, because extraction procedures and reagents used are different in each study. 
With regard to the same antioxidant activity, no significant differences were found among our geographic groups $(p>0.05)$, which demonstrate that all propolis exhibited excellent antioxidant activities regardless their botanical and geographical origins.

\subsection{Hyaluronidase Inhibitory Activity}

Hyaluronic acid is a component of articular cartilage that plays an important role in tissues' renovation. Its degradation, by the hyaluronidase enzyme, is likely to cause pain, inflammation and bone loss [50]. Therefore, the quantification of hyaluronidase inhibition is an indirect way to assess the anti-inflammatory activity. In the studied propolis, hyaluronidase inhibitory activity ranged from $0 \%$ to $68.20 \%$ with a propolis concentration of $10 \mathrm{mg} / \mathrm{mL}$ (Figure 3). Similar results were observed by other authors. Inhibition rates between 10-20\% were obtained for Portuguese propolis at $10 \mathrm{mg} / \mathrm{mL}$, and between $53.76 \%$ and $75.79 \%$ at a concentration of $25 \mathrm{mg} / \mathrm{mL}$ [51]. Around $9 \%$ inhibition was reported for Brazilian propolis from stingless bees at $10 \mathrm{mg} / \mathrm{mL}$ and a $43.06 \%$ anti-inflammatory activity at $75 \mathrm{mg} / \mathrm{mL}$ [52]. The literature shows that anti-inflammatory activity values are highly dependent on the concentration of propolis working solutions such that, similar to other parameters previously mentioned (such as phenolics' concentrations and antioxidant activities), it is of the utmost importance to standardize the analysis method for hyaluronidase inhibition in the next future.

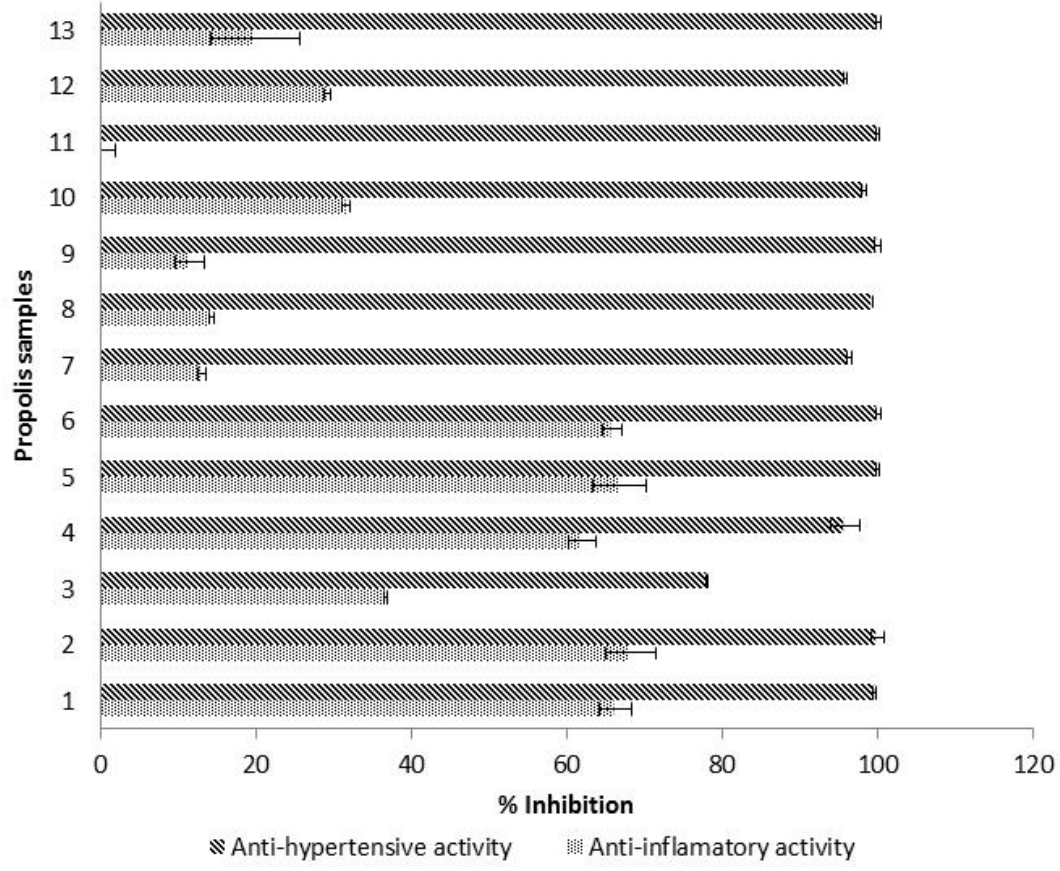

Figure 3. Mean values $(n=3)$ of hyaluronidase inhibitory activity and ACE inhibitory activity, expressed as $\%$ of inhibition. Error bars represent the standard deviation for each data point.

In our study, the samples with low hyaluronidase inhibition values also showed low results for ferulic acid contents and for flavanones/dihydroflavonols concentrations. Therefore, it is likely that both ferulic acid and the group flavanones/dihydroflavonols are the main compounds responsible for a potential anti-inflammatory activity of propolis.

\subsection{ACE Inhibitory Activity}

The ACE inhibitory activity of propolis samples $(10 \mathrm{mg} / \mathrm{mL})$, expressed as \% of inhibition of angiotensin I converting enzyme (ACE) is shown in Figure 3. ACE inhibitory activity was higher than $95 \%$ for all the samples except for one propolis $(78 \%)$, which contained the lowest amount of flavanols (27.89 $\mathrm{mg} \mathrm{C/g}$ ). Our results agreed with literature, because a previous study carried out on 
Tunisian propolis also showed an ACE inhibition higher than 90\% [17]. In comparison with other products, propolis exhibited a considerably higher ACE-inhibitory activity percentage, because values obtained for fermented milk (20-90\%) [22], honeys at 50\% (17-71\%) [53], Echium vulgare honeys at 50\% (94.2\%) [54], mung bean and rice protein hydrolysates (52-96\%) [55] as well as Ramie (Boehmeria nivea Gaudich) leaves extracts (51\% inhibition) [56], were considerably lower. Therefore, the use of propolis could modulate the ACE, providing an effective control of hypertension, which is an important strategy to decrease the risk for cardiovascular diseases.

In pharmacies, the main compounds with ACE inhibitory activity are captopril-related antihypertensive drugs. However, these synthetic ACE inhibitors are known to produce cough, skin rashes and angioedema [57]. For this reason, it is of paramount importance to research other substances, especially natural products that could inhibit ACE to some extent. Most studies are focussed in peptides obtained from different food proteins, such as egg white [58], soybean [59], seafood $[60,61]$ and other protein rich foods. Other studies show that some phenolic compounds, such as flavonoids, also exhibit ACE inhibition activity [62], so flavonoid extracts or products rich in flavonoids might be used against hypertension. With regard to propolis, further studies are still necessary to research the ACE inhibitory action at various concentrations in order to check if this activity depends on propolis concentration, as it was described for other products $[60,61]$. It is also necessary to perform more in vivo studies, similar to the study investigating Brazilian green propolis for the prevention of hypertension in rats [63].

In this study, higher values of ACE inhibition were found in samples with higher amounts of catechin and $p$-coumaric acid, so these two phenolic compounds could be responsible for a possible antihypertensive capacity of propolis. Indeed, catechin together with other flavonoids have been described as effective ACE inhibitors [64].

\subsection{Correlations}

All propolis showed antioxidant, hyaluronidase inhibitory and ACE inhibitory activities that could be due to different compounds or to the synergy of different constituents. Different compounds were reported to display the same activity, sometimes in the same order of magnitude [1]. Total phenolics exhibited a positive correlation with total flavones/flavonols $(r=0.7193)$. TEAC was positively correlated with total phenolics $(r=0.7151)$ and total flavones/flavonols $(r=0.5282)$, agreeing with other researchers' results for propolis from Portugal, Morocco and Spain $[26,29,31]$, showing furthermore in our study a positive correlation with caffeic acid concentration $(r=0.5171)$. Negative correlations were obtained between the antioxidant activity against hydroxyl radical and total phenolics $(r=-0.5563)$ and total flavones/flavonols $(r=-0.7101)$. Thus, it is likely that antioxidant activity against hydroxyl radicals could be more related to other propolis compounds, such as vitamins, proteins, organic acids, and minerals [2]. Hyaluronidase inhibitory activity was correlated with ferulic acid $(r=0.7245)$. It is important to highlight the fact that ferulic acid was one of the phenolic compounds common to all of our samples, and even although this acid was not described as efficient on cell proliferation inhibition [65], it should be deeper researched as an interesting anti-inflammatory related compound. Hyaluronidase inhibitory activity was also moderately correlated with total flavanones/dihydroflavonols $(r=0.3040)$. Samples with different polyphenols' concentrations showed an almost equal hyaluronidase inhibitory activity, suggesting that these compounds were not the unique factors responsible for this activity [51]. As for ACE inhibitory activity, in a previous study carried out on honeys no significant correlations were observed between ACE inhibitory activity and phenols or antioxidant capacity [53]. In our research on propolis, ACE inhibitory activity was negatively correlated with total flavones/flavonols $(r$ $=-0.5451)$ and total flavanones/dihydroflavonols $(r=-0.5540)$ and positively correlated with flavanols $(r=0.3766)$, catechin $(r=0.6096)$ and $p$-coumaric acid $(r=0.5575)$. This last correlation is interesting since $p$-coumaric acid was another phenolic compound that was present in all the samples of our study. It is likely that flavanols in synergy with $p$-coumaric acid and other propolis components are responsible for a potential antihypertensive activity. It is also important to highlight that some 
other phenolic compounds, not identified in this study but present in the propolis samples, could be responsible for these activities.

\section{Conclusions}

This study highlights the importance of setting up and proposing harmonized propolis analysis methods and the expression of results for phenolic compounds and antioxidant capacities, since common extraction procedures, reagents, and the expression of results are essential for efficient data comparison. With respect to the expression of results, we propose referring all values to $g$ propolis to overcome differences in the extraction procedure and final extract concentration among different methods.

HPLC-UV analysis showed that $p$-coumaric and ferulic acids were identified in all samples. All propolis also exhibited quantifiable values for the sums of naringenin+quercetin, apigenin+kaempferol and CAPE+galangin. Flavonoids were found in higher concentration than phenolic acids, with pinocembrin, catechin, caffeic acid phenethyl ester (CAPE), and galangin being the main flavonoids.

Regardless of their origins, all propolis exhibited strong TEAC, hydroxyl, and superoxide radicals, meaning that they could be used to prevent product spoilage in food, pharmaceutical, cosmetic, and other companies. They might also play an important physiological role because of their capacity to scavenge hydroxyl and superoxide radicals related to cell damage and related diseases.

Solutions of $10 \mathrm{mg} / \mathrm{mL}$ propolis showed both hyaluronidase and ACE inhibitory activities. Hyaluronidase inhibitory activity was positively correlated with ferulic acid and to less extent to flavanones/dihydroflavonols. ACE inhibitory activity was positively correlated with catechin and $p$-coumaric acid, and to less extent to flavanols. The potent effect of propolis to inhibit ACE underlines its interesting antihypertensive potential.

Supplementary Materials: The following are available online at http://www.mdpi.com/2076-3921/9/1/75/s1, Table S1: Limit of detection and quantification of phenolic compounds $(\mathrm{mg} / \mathrm{mL})$ by HPLC-UV, Table S2: Antioxidant activity against $\mathrm{ABTS}^{\bullet+}$ radical $(\mu \mathrm{mol}$ Trolox/g) of standard phenolic compounds, Table S3: TEAC values $(\mu \mathrm{mol}$ Trolox/g) of the propolis samples calculated from the addition of the TEAC contribution of each phenolic compound quantified by HPLC-UV, and actual TEAC values of the propolis samples.

Author Contributions: Conceptualization, M.Á.F.-M. and M.T.S.; methodology, S.M.O., M.Á.F.-M. and M.T.S.; software, S.M.O.; validation, S.M.O.; formal analysis, S.M.O. and M.T.S.; investigation, S.M.O., P.M., P.A. and A.d.P.; resources, S.M.O. and M.T.S.; data curation, S.M.O., M.Á.F.-M. and M.T.S.; writing-original draft preparation, S.M.O. and M.T.S.; writing—review and editing, S.M.O. and M.T.S.; visualization, S.M.O., M.Á.F.-M. and M.T.S.; supervision, S.M.O., M.Á.F.-M. and M.T.S.; project administration, S.M.O. and M.T.S. All authors have read and agreed to the published version of the manuscript.

Funding: This research received no external funding.

Acknowledgments: This study was carried out on propolis that had been collected for an international ring trial research within the Propolis working group of the International Honey Comission. The authors very warmly thank all the participants of the ring trial, who kindly gave their permission for the publication of this manuscript: V Bankova (Bulgaria), G Beckh (Germany), ÖG Çelemli (Turkey), T Daştan (Turkey), S Gardini (Italy), S Georgé (France), C Kunert (Germany), L Paulo (Portugal), A Pereyra (Slovenia), C Tananaki (Greece) and M Vilas Boas (Portugal; leader of the group). A special gratitude goes to H Schreiter (Germany) for gathering, preparing and distributing all the propolis samples.

Conflicts of Interest: The authors declare no conflict of interest.

\section{References}

1. Bankova, V. Recent trends and important developments in propolis research. eCAM 2005, 2, 29-32. [CrossRef] [PubMed]

2. Bogdanov, S.; Bankova, V. Propolis: Origin, Production, Composition. The Propolis Book, Chapter 1. 2017. Available online: http://www.bee-hexagon.net (accessed on 11 April 2019).

3. Jerković, I.; Mastelić, J. Volatile compounds from leaf-buds of Populus nigra L. (Salicaceae). Phytochemistry 2003, 63, 109-113. [CrossRef] 
4. Salatino, A.; Teixeira, E.W.; Negri, G.; Message, D. Origin and chemical variation of Brazilian propolis. Evid.-Based Complement. Altern. Med. 2005, 2, 33-38. [CrossRef] [PubMed]

5. Kumazawa, S.; Hamasaka, T.; Nakayama, T. Antioxidant activity of propolis of various geographic origins. Food Chem. 2004, 84, 329-339. [CrossRef]

6. Bogdanov, S. Propolis: Biological Properties and Medical Applications. The Propolis Book, Chapter 2. 2017. Available online: http://www.bee-hexagon.net (accessed on 10 January 2019).

7. Mehta, J.; Rayalam, S.; Wang, X. Cytoprotective effects of natural compounds against oxidative stress. Antioxidant 2018, 7, 147. [CrossRef]

8. Karapetsas, A.; Voulgaridou, G.P.; Konialis, M.; Tsochantaridis, I.; Kynigopoulos, S.; Lambropoulou, M.; Stavropoulou, M.I.; Stathopoulou, K.; Aligiannis, N.; Bozidis, P.; et al. Propolis extracts inhibit UV-induced photodamage in human experimental in vitro skin models. Antioxidant 2017, 8, 125. [CrossRef]

9. Oršolić, N.; Jurčević, I.L.; Đikić, D.; Rogić, D.; Odeh, D.; Balta, V.; Junaković, E.P.; Terzić, S.; Jutrić, D. Effect of propolis on diet-induced hyperlipidemia and atherogenic indices in mice. Antioxidant 2019, 8, 156. [CrossRef]

10. Bankova, V.; Popova, M.; Trusheva, B. New emerging fields of application of propolis. Maced. J. Chem. Chem. Eng. 2016, 35, 1-11. [CrossRef]

11. European Commission. 2017. Available online: http://ec.europa.eu/food/safety/labelling_nutrition/claims/ register/public/?event=search (accessed on 12 June 2019).

12. Prior, R.L.; Wu, X.; Schaich, K. Standardized methods for the determination of antioxidant capacity and phenolics in foods and dietary supplements. J. Agric. Food Chem. 2005, 53, 4290-4302. [CrossRef]

13. Meda, A.; Lamien, C.E.; Romito, M.; Millogo, J.; Nacoulma, O.G. Determination of the total phenolic, flavonoid and proline content in Burkina Fasan honey, as well as their radical scavenging activity. Food Chem. 2005, 91, 571-577. [CrossRef]

14. Popova, M.; Bankova, V.; Butovska, D.; Petkov, V.; Nikolova-Damyanova, B.; Sabatini, A.G.; Marcazzan, G.L.; Bogdanov, S. Validated methods for the quantification of biologically active constituents of poplar-type propolis. Phytochem. Anal. 2004, 15, 235-240. [CrossRef] [PubMed]

15. Pękal, A.; Pyrzynska, K. Evaluation of aluminium complexation reaction for flavonoid content assay. Food Anal. Meth. 2014, 7, 1776-1782. [CrossRef]

16. Falcão, S.I.; Tomás, A.; Vale, N.; Gomes, P.; Freire, C.; Vilas-Boas, M. Phenolic quantification and botanical origin of Portuguese propolis. Ind. Crop. Prod. 2013, 49, 805-812. [CrossRef]

17. Gargouri, W.; Osés, S.M.; Fernández-Muiño, M.A.; Sancho, M.T.; Kechaour, N. Evaluation of bioactive compounds and biological activities of Tunisian propolis. LWT-Food Sci. Technol. 2019, 111, 328-336. [CrossRef]

18. Sancho, M.T.; Pascual-Maté, A.; Rodríguez-Morales, E.G.; Osés, S.M.; Escriche, I.; Periche, A.; Fernández-Muiño, M.A. Critical assessment of antioxidant-related parameters of honey. Int. J. Food Sci. Technol. 2016, 51, 30-36. [CrossRef]

19. Koracevic, D.; Koracevic, G.; Djordjevic, V.; Andrejevic, S.; Cosic, V. Method for the measurement of antioxidant activity in human fluids. J. Clin. Pathol. 2001, 54, 356-361. [CrossRef]

20. Nagai, T.; Sakai, M.; Inoue, R.; Inoue, H.; Suzuki, N. Antioxidative activities of some commercially honeys, royal jelly, and propolis. Food Chem. 2001, 75, 237-240. [CrossRef]

21. Ferreres, F.; López, G.; Gil-Izquierdo, A.; Andrade, P.; Sousa, C.; Mouga, T.; Valentao, P. Phlorotannin extracts from fucales characterized by HPLC-DAD-ESI-MS ${ }^{\mathrm{n}}$ : Approaches to hyaluronidase inhibitory capacity and antioxidant properties. Mar. Drugs 2012, 10, 2766-2781. [CrossRef]

22. Gonzalez-Gonzalez, C.R.; Tuohy, K.M.; Jauregi, P. Production of angiotensin-I-converting enzyme (ACE) inhibitory activity in milk fermented with probiotic strains: Effects of calcium, $\mathrm{pH}$ and peptides on the ACE-inhibitory activity. Int. Dairy J. 2011, 21, 615-622. [CrossRef]

23. Feás, X.; Pacheco, L.; Iglesias, A.; Estevinho, L.M. Use of propolis in the sanitization of lettuce. Int. J. Mol. Sci. 2014, 15, 12243-12257. [CrossRef]

24. Woisky, R.G.; Salatino, A. Analysis of propolis: Some parameters and procedures for chemical quality control. J. Apic. Res. 1998, 37, 99-105. [CrossRef]

25. Osés, S.M.; Pascual-Maté, A.; Fernández-Muiño, M.A.; López-Díaz, T.M.; Sancho, M.T. Bioactive properties of honey with propolis. Food Chem. 2016, 196, 1215-1223. [CrossRef] [PubMed]

26. Serra-Bonvehí, J.; Lacalle-Gutiérrez, A. Antioxidant activity and total phenolics of propolis from the Basque country (Northeastern Spain). J. Am. Oil Chem. Soc. 2011, 88, 1387-1395. [CrossRef] 
27. Socha, R.; Galkowska, D.; Bugaj, M.; Juszczak, L. Phenolic composition and antioxidant activity of propolis from various regions of Poland. Nat. Prod. Res. 2015, 29, 416-422. [CrossRef]

28. Yang, H.; Dong, Y.; Du, H.; Shi, H.; Peng, Y.; Li, X. Antioxidant compounds from propolis collected in Anhui, China. Molecules 2011, 16, 3444-3455. [CrossRef]

29. Miguel, M.D.G.; Nunes, S.; Dandlen, S.A.; Cavaco, A.M.; Antunes, M.D. Phenols and antioxidant activity of hydro-alcoholic extracts of propolis from Algarve, South of Portugal. Food Chem. Toxicol. 2010, 48, 3418-3423. [CrossRef]

30. Mavri, A.; Abramovič, H.; Polak, T.; Bertoncelj, J.; Jamnik, P.; Možina, S.S.; Jeršek, B. Chemical properties and antioxidant and antimicrobial activities of Slovenian propolis. Chem. Biodivers. 2012, 9, 1545-1558. [CrossRef]

31. Miguel, M.D.G.; Doughmi, O.; Aazza, S.; Antunes, D.; Lyoussi, B. Antioxidant, anti-inflammatory and acetylcholinesterase inhibitory activities of propolis from different regions of Morocco. Food Sci. Biotechnol. 2014, 23, 313-322. [CrossRef]

32. Kalogeropoulos, N.; Konteles, S.J.; Troullidou, E.; Mourtzinos, I.; Karathanos, V.T. Chemical composition, antioxidant activity and antimicrobial properties of propolis extracts from Greece and Cyprus. Food Chem. 2009, 116, 452-461. [CrossRef]

33. Falcão, S.I.; Vale, N.; Cos, P.; Gomes, P.; Freire, C.; Maes, L.; Vilas-Boas, M. In vitro evaluation of Portuguese propolis and floral sources for antiprotozoal, antibacterial and antifungal activity. Phytother. Res. 2013, 28, 437-443. [CrossRef]

34. Coelho, J.; Falcão, S.I.; Vale, N.; Almeida-Muradian, L.B.; Vilas-Boas, M. Phenolic composition and antioxidant activity assessment of southeastern and south Brazilian propolis. J. Apic. Res. 2017, 56, 21-31. [CrossRef]

35. Bankova, V.; Bertelli, D.; Borba, R.; Conti, B.J.; da Silva Cunha, I.B.; Danert, C.; Eberlin, M.N.; Falcão, S.I.; Isla, M.I.; Moreno, M.I.N.M.; et al. Standard methods for Apis mellifera propolis research. J. Apic. Res. 2016, 58, 1-49. [CrossRef]

36. Miguel, M.G.; Nunes, S.; Dandlen, S.A.; Cavaco, A.M.; Antunes, M.D. Phenols, flavonoids and antioxidant activity of aqueous and methanolic extracts of propolis (Apis mellifera L.) from Algarve, South Portugal. Food Sci. Technol. 2014, 34, 16-23. [CrossRef]

37. Dubero-Sime, M.A.; Redi-Abshiro, M.; Zewde, T. Total phenols and antioxidant activities of natural honeys and propolis collected from different geographical regions of Ethiopia. Bull. Chem. Soc. Ethiop. 2015, 29, 163-172. [CrossRef]

38. Auamcharoen, W.; Phankaew, C. Antibacterial activity and phenolic content of propolis from four different areas of Thailand. Int. J. Pharm. Sci. Rev. Res. 2016, 37, 77-82.

39. Molnár, S.; Mikuska, K.; Patonay, K.; Sisa, K.; Daood, H.G.; Némedi, E.; Kiss, A. Comparative studies on polyphenolic profile and antimicrobial activity of propolis samples selected from distinctive geographical areas of Hungary. Food Sci. Technol. Int. 2017, 23, 349-357. [CrossRef]

40. Okińczyc, P.; Szumny, A.; Szperlik, J.; Kulma, A.; Franiczek, R.; Żbikowska, B.; Krzyżanowska, B.; Sroka, Z. Profile of polyphenolic and essential oil composition of Polish propolis, black poplar and aspens buds. Molecules 2018, 23, 1262. [CrossRef]

41. Escriche, I.; Juan-Borrás, M. Standardizing the analysis of phenolic profile in propolis. Food Res. Int. 2018, 106, 834-841. [CrossRef]

42. Gardini, S.; Bertelli, D.; Marchetti, L.; Graziosi, R.; Pinetti, D.; Plessi, M.; Marcazzan, G.L. Chemical composition of Italian propolis of different ecoregional origin. J. Apic. Res. 2018, 57, 639-647. [CrossRef]

43. Kumazawa, S.; Serrra Bonvehí, J.; Torres, C.; Mok-Ryeon, A.; Orantes Bermejo, F.J. Chemical and functional characterization of propolis collected from east Andalusia (Southern Spain). Phytochem. Anal. 2013, 24, 608-615. [CrossRef]

44. Regueira Neto, M.S.; Tintino, S.R.; Pereira da Silva, A.R.; Costa, M.S.; Boligon, A.A.; Maties, E.F.F.; de Queiroz, V.; Menezes, I.R.A.; Melo, H.D. Seasonal variation of Brazilian red propolis: Antibacterial activity, synergistic effect and phytochemical sreening. Food Chem. Toxicol. 2017, 107, 572-580. [CrossRef] [PubMed]

45. Calegari, M.A.; Prasniewski, A.; Da Silva, C.; Sado, R.Y.; Maia, F.M.C.; Tonial, L.M.S.; Oldoni, T.L.C. Propolis from Southwest of Parana produced by selected bees: Influence of seasonality and food supplementation of antioxidant activity and phenolic profile. An. Acad. Bras. Cienc. 2017, 89, 45-55. [CrossRef] [PubMed]

46. Kurek-Górecka, A.; Rzepecka-Stojko, A.; Górecki, M.; Stojko, J.; Sosada, M.; Świerczek-Zięba, G. Structure and antioxidant activity of polyphenols derived from propolis. Molecules 2014, 19, 78-101. [CrossRef] 
47. Nagai, T.; Inoue, R.; Kanamori, N.; Suzuki, N.; Nagashima, T. Characterization of honey from different floral sources. Its functional properties and effect of honey species on storage of meat. Food Chem. 2006, 97, 256-262. [CrossRef]

48. Marquele, F.D.; Di Mambro, V.M.; Georgetti, S.R.; Casagrande, R.; Valim, Y.M.L.; Fonseca, M.J.V. Assessment of the antioxidant activities of Brazilian extracts of propolis alone and in topical pharmaceutical formulations. J. Pharm. Biomed. Anal. 2005, 39, 455-462. [CrossRef] [PubMed]

49. Nagai, T.; Inoue, R.; Inoue, H.; Suzuki, N. Preparation and antioxidant properties of water extract of propolis. Food Chem. 2003, 80, 29-33. [CrossRef]

50. Libby, P.; Ridker, P.M.; Maseri, A. Inflammation and atherosclerosis. Circulation 2002, 105, 1135-1143. [CrossRef]

51. Silva, J.C.; Rodrigues, S.; Feás, X.; Estevinho, L.M. Antimicrobial activity, phenolic profile and role in the inflammation of propolis. Food Chem. Toxicol. 2012, 50, 1790-1795. [CrossRef]

52. Ferreira Campos, J.; Pereira dos Santos, U.; dos Santos da Rocha, P.; Damião, M.J.; Perrella Balestieri, J.B.; Lima Cardoso, C.A.; Paredes-Gamero, E.J.; Estevinho, L.M.; de Picoli Souza, K.; dos Santos, E.L. Antimicrobial, antioxidant, anti-inflammatory, and cytotoxic activities of propolis from the stingless bee Tetragonisca fiebrigi (Jataí). Evid.-Based Complement. Altern. Med. 2015, 2015, 296186. [CrossRef]

53. León-Ruiz, V.; González-Porto, A.V.; Al-Habsi, N.; Vera, S.; San Andrés, M.P.; Jauregi, P. Antioxidant, antibacterial and ACE-inhibitory activity of four monofloral honeys in relation to their chemical composition. Food Funct. 2013, 4, 1617-1624. [CrossRef]

54. Nagai, T.; Tanoue, Y.; Kai, N.; Suzuki, N. Functional Property of Honey from Echium vulgare. Food Nutr. Sci. 2012, 3, 614-620. [CrossRef]

55. Li, G.H.; Liu, H.; Shi, Y.H.; Le, G.W. Direct spectrophotometric measurement of angiotensin I-converting enzyme inhibitory activity for screening bioactive peptides. J. Pharm. Biomed. Anal. 2005, 37, 219-224. [CrossRef] [PubMed]

56. Nho, J.W.; Hwang, I.G.; Kim, H.Y.; Lee, Y.R.; Woo, K.S.; Hwang, B.Y.; Chang, S.J.; Lee, J.; Jeong, H.S. Free radical scavenging, angiotensin I-converting enzyme (ACE) inhibitory, and in vitro anticancer activities of ramie (Boehmeria nivea) leaves extracts. Food Sci. Biotechnol. 2010, 19, 383-390. [CrossRef]

57. Vercruysse, L.; Van Camp, J.; Smagghe, G. ACE inhibitory peptides derived from enzymatic hydrolysates of animal muscle protein: A review. J. Agric. Food Chem. 2005, 53, 8106-8115. [CrossRef] [PubMed]

58. Ding, L.; Zhang, Y.; Jiang, Y.; Wang, L.; Liu, B.; Liu, J. Transport of egg white ACE-inhibitory peptide, Gln-Ile-Gly-Leu-Phe, in human intestinal Caco-2 cell monolayers with cytoprotective effect. J. Agric. Food Chem. 2014, 62, 3177-3182. [CrossRef] [PubMed]

59. Lee, J.S.; Mi, A.Y.; Koo, S.H.; Baek, H.H.; Lee, H.G. Antioxidant and ACE inhibitory activities of soybean hydrolysates: Effect of enzyme and degree of hydrolysis. Food Sci. Biotechnol. 2008, 17, 873-877.

60. Yu, Y.; Fan, F.; Wu, D.; Yu, C.; Wang, Z.; Du, M. Antioxidant and ACE inhibitory activity of enzymatic hydrolysates from Ruditapes philippinarum. Molecules 2018, 23, 1189. [CrossRef]

61. Zhang, Q.; Song, C.; Zhao, J.; Shi, X.; Sun, M.; Liu, J.; Fu, Y.; Jin, W.; Zhu, B. Separation and characterization of antioxidative and angiotensin converting enzyme inhibitory peptide from jellyfish gonad hydrolysate. Molecules 2018, 23, 94. [CrossRef]

62. Chen, S.Y.; Chu, C.C.; Chyau, C.C.; Yang, J.W.; Duh, P.D. Djulis (Chenopoliu formosanum) and its bioactive compounds affect vasodilation, angiotensin convertin enzyme activity, and hypertension. Food Biosci. 2019, 32, 100469. [CrossRef]

63. Maruyama, H.; Sumitou, Y.; Sakamoto, T.; Araki, Y.; Hara, H. Antihypertensive effects of flavonoids isolated from Brazilian green propolis in spontaneously hypertensive rats. Biol. Pharm. Bull. 2009, 32, 1244-1250. [CrossRef]

64. Balasuriya, N.; Rupasinghe, H.P. Antihypertensive properties of flavonoid-rich apple peel extract. Food Chem. 2012, 135, 2320-2325. [CrossRef] [PubMed]

65. Seyhan, M.F.; Yilmaz, E.; Timirci-Kahraman, Ö.; Saygili, N.; Kisakesen, H.I.; Gazioğlu, S.; Gören, A.C.; Eronat, A.P.; Ceviz, A.B.; Öztürk, T.; et al. Different propolis samples, phenolic content, and breast cancer cell lines: Variable cytotoxicity ranging from ineffective to potent. IUBMB Life 2019, 71, 619-631. [CrossRef] [PubMed]

(C) 2020 by the authors. Licensee MDPI, Basel, Switzerland. This article is an open access article distributed under the terms and conditions of the Creative Commons Attribution (CC BY) license (http://creativecommons.org/licenses/by/4.0/). 